\title{
Psychological and Forensic Challenges Regarding Youth Consumption of Pornography: A Narrative Review
}

\author{
Aina M. Gassó $1,2, *$ (D) and Anna Bruch-Granados ${ }^{2}$ \\ 1 Faculty of Law, Universitat Internacional de Catalunya, 08017 Barcelona, Spain \\ 2 Department of Forensic Psychology, Instituto de Psiquiatría y Psicología Clínica de Barcelona, \\ 08021 Barcelona, Spain; annabruchgranados@gmail.com \\ * Correspondence: ainagasso@uic.es
}

Citation: Gassó, A.M.;

Bruch-Granados, A. Psychological and Forensic Challenges Regarding Youth Consumption of Pornography: A Narrative Review. Adolescents 2021, 1, 108-122. https://doi.org/10.3390/ adolescents1020009

Academic Editors: Larry F. Forthun and Kate Tilleczek

Received: 8 March 2021

Accepted: 21 March 2021

Published: 7 April 2021

Publisher's Note: MDPI stays neutral with regard to jurisdictional claims in published maps and institutional affiliations.

Copyright: (c) 2021 by the authors. Licensee MDPI, Basel, Switzerland. This article is an open access article distributed under the terms and conditions of the Creative Commons Attribution (CC BY) license (https:// creativecommons.org/licenses/by/ $4.0 /)$.

\begin{abstract}
Nowadays, technology has become part of the daily activities of a large part of the population. Many of the activities and development and socialization processes of minors and young people have been transferred to the online world, generating attention and concern from the educational, scientific, and forensic communities. One of the most worrying issues derived from this new online world is the consumption of pornography by teens. The objective of this literature review is to draw attention to the consequences and emotional disturbances derived from the consumption of pornography in young people, as well as the forensic implications of this phenomenon, among which are paraphilias, perpetration, and victimization of sexual assaults, and the development of new forms of online sexual victimization. The main findings suggest that the first contact with pornography starts at the age of 8 years old, with important behavioral and psychological consequences, such as hypersexualization, emotional disturbances, and the perpetuation of gender inequality. Furthermore, pornography consumption by youth has been linked to the exacerbation of paraphilias, an increase in sexual aggression perpetration and victimization, and, finally, it has been linked to an increase in online sexual victimization. Implications and future lines of research are discussed.
\end{abstract}

Keywords: pornography; adolescents; forensic challenges; youth; sexuality

\section{Introduction}

From a psychological perspective, sexuality is understood as the conjunction between anatomical, physiological, and psychological factors, and all the emotional and behavioral phenomena tied to sex, which start consolidating during adolescence. Sexual identity starts developing during childhood and can be modified by different factors, including social and external ones. From that perspective, having access to pornography becomes an important and relevant issue for teenagers and young people [1]. Young people have been defined by the World Health Organization as individuals 10-24 years of age, and, for the purpose of this investigation, we will refer to youth and young people independently, understanding they are individuals aged between 10 and 24 years old.

Since the inclusion of the internet and ICT (Information and Communication Technology) in daily activities, society has experienced changes in many areas, and social interaction has particularly evolved at a fast pace. The development of new intelligent devices with immediate and autonomous internet access has enabled instant communication and unlimited and immediate access to any type of content, including pornography. Pornography is not a recent or new phenomena and its appearance can be traced back to the Ancient Greeks [2]; however, the new pornography that has appeared with the irruption of new technological devices has different and unique intrinsic characteristics, which differentiate it from the "old pornography". Ballester et al. [1] define it with the following: 1. Image quality: New pornography is based on high-quality recordings that are constantly improving in image quality. 
2. Affordable: New pornography is widely affordable and most of it is completely free.

3. Accessible: There is a wide and unlimited offering, which can be accessed without restrictions and which can be seen from any device.

4. Unlimited sexual content: Sexual practices displayed in "new pornography" have no limits, including risky sexual practices or even illegal ones.

The literature shows that between 7 and 59\% of adolescents intentionally access and consume pornography [3]. The wide range and variability in the reported prevalence rates of pornography consumption in adolescents are due to the differences in samples, age of participants, and means of consumption. Prevalence rates for any type of consumption (intentional versus unintentional consumption) can range from 7 to $71 \%$, depending on the measures used [3]. Furthermore, studies analyzing gender differences found that $93 \%$ of boys and $52 \%$ of girls aged between 16 and 19 years old had watched pornographic material in the past six months [4]. These gender differences were also reported by Ballester, Orte, and Pozo [5], whose results show that online pornography consumption is significantly higher with boys $(90.5 \%)$ than with girls $(50 \%)$, with male participants also reporting a higher frequency of consumption than female participants.

Research focusing on age differences found that $50 \%$ of Spanish teenagers aged between 14 and 17 years old watch online pornography [6]. Furthermore, Ballester et al. [1] reported that almost $70 \%$ of Spanish young people aged between 16 and 29 years old consume pornography. Their results show that the age of first contact with pornography has advanced in Spain, with kids having their first contact with pornography at a mean age of 8 years old, and generalized consumption starting at 13-14 years old [1].

The spread in ownership of mobile phones means that pornography can be accessed virtually anywhere and is watched by youth both privately and in groups. This new way of accessing and consuming pornography has a clear impact on sexual behavior, gender relationships, sexual aggression, and sexuality, especially on minors, who are sensibly vulnerable to pornographic content, as they are developing their sexuality [3].

A recent study stated that $40.7 \%$ of participants reported having suffered negative consequences related to pornography consumption, either at a personal, social, academic, or professional level [7]. Many authors have pointed out that pornography consumption in minors is associated with diverse negative consequences $[1,5,7,8]$. For example, Burbano and Brito [8] stated that watching pornography has a direct impact on the psychosexual development of teenagers, creating misleading and inaccurate educational models regarding sexuality. In addition, Peter and Valkenburg [3] found that watching pornography as a teenager is associated with the appearance and increase of risky sexual behaviors, such as having unprotected sex, having sexual intercourse with many partners, or an increase in sexual aggression perpetration and victimization. Additionally, Burbano and Brito [8] showed that consuming pornography at early stages, especially as a minor, is associated with new forms of online sexual victimization, such as sexting or online grooming.

Furthermore, the literature has shown a link between the consumption of pornography by young people and forensic and legal implications. Recent studies have highlighted an association between an early consumption of sexually explicit material and the appearance and exacerbation of paraphilias such as voyeurism and exhibitionism $[9,10]$. Moreover, the research has pointed towards a modulated relationship between early consumption of pornography and compulsive consumption and an increase in sexual aggression perpetration by males and sexual aggression victimization in females [3]. Finally, recent findings suggest a link between early consumption of pornography and increased engagement in online sexual behaviors, such as sexting, that can lead to further online sexual victimization, such as sextortion or online grooming [11].

Thus, the aim of this paper was to analyze what is known so far about the impact and consequences that intentional pornography consumption has on young people, with a focus on the forensic challenges and implications that this phenomenon is having on youth. 


\section{Methods}

In recent years, the body of research regarding pornography consumption has increased. Several studies have highlighted the effects of such consumption on the social and sexual development of youth and further related forensic implications that can have negative psychological and legal consequences. This narrative review aims to identify empirical and non-empirical research addressing the association between pornography consumption in young people and the social, sexual, and psychological consequences, as well as further forensic implications. A narrative review is a publication that describes and discusses the state of the science of a specific topic or theme from a theoretical and contextual point of view [12]. For the purpose of this paper, a narrative review was conducted as a first approach and approximation to the state of the question regarding pornography consumption in youth, taking into account its limitations, including Spanish research, to previous reviews on the issue. We believe that since the publication of Peter and Valkenburg's (2016) systematic review, relevant contributions have been made regarding youths' intentional exposure to porn, and this study aims to review those and other contributions, including Spanish literature, to examine the actual state of the question. We consider this topic of considerable relevance to parents, the educational community, and health care practitioners working with young people who might be affected by this phenomenon.

Criteria for the inclusion in the review were as follows:

- Research (either empirical or non-empirical but excluding doctoral dissertations) exploring pornography consumption in adolescent and young population

- Research examining the association between pornography consumption in youth and the social, sexual, and psychological consequences

- Studies investigating the association between pornography consumption in youth and the legal or forensic implications

The data included in this review were collected throughout October, November, and December 2020. The search included empirical and non-empirical research from 2000 to 2020, and we included research both in English and Spanish. The following databases were searched: SCOPUS, PsychInfo, MEDLINE, and PUBMED, using the keywords "pornography", "youth", "adolescence", "minors", "teenagers", and "consequences". In addition, reference lists of reviewed articles were examined in relation to the topic of research. Young people have been defined by the World Health Organization as individuals 10-24 years of age, and, for the purpose of this investigation, we refer to youth and young people independently, understanding they are individuals aged between 10 and 24 years old. Furthermore, it should be noted that most of the reviewed studies did not specify the type of pornography used in their research (heterosexual, queer, feminist, etc.), and the studies that did, analyzed exclusively heterosexual pornography.

\section{Results}

Overall, 30 papers were included in the narrative review. Out of the 30 papers, 18 were in English (60\%) and 8 were in Spanish (26.7\%). Out of the total sample of reviewed papers, 18 were empirical articles (60\%), and the years of publication ranged from 2004 to 2020. The results regarding specific details of the analyzed papers are shown in Table 1.

Table 1. Details of studies included in the review.

\begin{tabular}{|c|c|c|c|c|c|c|}
\hline Citation & Year & Country & $\begin{array}{l}\text { Type of } \\
\text { Article }\end{array}$ & $\begin{array}{l}\mathbf{N}(\% \text { of } \\
\text { Women) }\end{array}$ & $\begin{array}{l}\text { Age } \\
\text { Range }\end{array}$ & Results \\
\hline $\begin{array}{l}\text { Ballester, L., Orte, } \\
\text { C., and Pozo, R. [5] }\end{array}$ & 2014 & Spain & $\mathrm{E}$ & 37 (43.2) & $16-22 * *$ & $\begin{array}{l}\text { Online porn consumption can have an } \\
\text { influence on the sexual attitudes, moral } \\
\text { values, and the sexual activity of youth. }\end{array}$ \\
\hline $\begin{array}{l}\text { Ballester, L., Orte, } \\
\text { C., and Pozo, R. [1] }\end{array}$ & 2019 & Spain & $\mathrm{NE}$ & - & $16-22 * *$ & $\begin{array}{l}\text { Males consume more pornography. Porn } \\
\text { consumption is associated with the } \\
\text { ritualization of sexuality and greater violent } \\
\text { sexual practices. }\end{array}$ \\
\hline
\end{tabular}


Table 1. Cont.

\begin{tabular}{|c|c|c|c|c|c|c|}
\hline Citation & Year & Country & $\begin{array}{l}\text { Type of } \\
\text { Article }\end{array}$ & $\begin{array}{l}\text { N (\% of } \\
\text { Women) }\end{array}$ & $\begin{array}{l}\text { Age } \\
\text { Range }\end{array}$ & Results \\
\hline $\begin{array}{l}\text { Barroso, L. and } \\
\text { Sanjuán, C. [13] }\end{array}$ & 2020 & Spain & $\mathrm{E}$ & 1680 & 14-17 & $\begin{array}{l}\text { Pornography use in adolescents has been } \\
\text { linked to risky sexual practices, emulation } \\
\text { of porn videos in real life, violent sexual } \\
\text { behavior, online grooming, and sexting. }\end{array}$ \\
\hline $\begin{array}{l}\text { Bonino, S., } \\
\text { Ciairano, S., } \\
\text { Rabaglietti, E., and } \\
\text { Cattelino, E. [14] }\end{array}$ & 2006 & Italy & $\mathrm{E}$ & $804(42)$ & 12-19 & $\begin{array}{l}\text { Pornography consumption is associated } \\
\text { with sexual violence (both active and } \\
\text { passive) and unwanted sex. }\end{array}$ \\
\hline $\begin{array}{l}\text { Burbano, M. V. T., } \\
\text { and Brito, J. P. S. [8] }\end{array}$ & 2019 & Ecuador & $\mathrm{E}$ & $50(-)$ & $12-14$ & $\begin{array}{l}\text { Online porn consumption can have an } \\
\text { influence on the sexual attitudes, moral } \\
\text { values, and the sexual activity of youth. }\end{array}$ \\
\hline $\begin{array}{l}\text { de Alarcón, R., } \\
\text { de la Iglesia, J. I., } \\
\text { Casado, N. M., and } \\
\text { Montejo, A. L. [15] }\end{array}$ & 2019 & Spain & NE & - & - & $\begin{array}{l}\text { Pornography consumption has an addictive } \\
\text { potential, considering the Triple A } \\
\text { influence. Problematic use of pornography } \\
\text { might have adverse effects on sexual } \\
\text { development and functionality, especially } \\
\text { amongst youth. }\end{array}$ \\
\hline Echeburúa, E. [16] & 2012 & Spain & NE & - & - & $\begin{array}{l}\text { One of the most frequent behaviors } \\
\text { associated with sex addiction is } \\
\text { pornography consumption. }\end{array}$ \\
\hline $\begin{array}{l}\text { Efrati, Y., and } \\
\text { Gola, M. [17] }\end{array}$ & 2018 & Israel & $\mathrm{E}$ & $\begin{array}{l}1.182(57.7) \\
618(44.8)\end{array}$ & 14-18 & $\begin{array}{l}\text { Adolescents who present compulsive } \\
\text { sexual behavior (CSB) have a higher } \\
\text { frequency of pornography use and more } \\
\text { sex-related online activities, among other } \\
\text { characteristic features. }\end{array}$ \\
\hline $\begin{array}{l}\text { Esquit, L and } \\
\text { Alvarado, Y. [18] }\end{array}$ & 2016 & Guatemala & $\mathrm{E}$ & $30(33)$ & 13-17 & $\begin{array}{l}\text { Pornography impacts psychosexual } \\
\text { development and contributes to the } \\
\text { distortion of intimate partner relationships } \\
\text { (by contributing to the normalization of } \\
\text { pathological sexual behavior). }\end{array}$ \\
\hline Fagan, P. F. [19] & 2009 & USA & NE & - & - & $\begin{array}{l}\text { Pornography is a visual representation of } \\
\text { sexuality, which distorts the concept of } \\
\text { intimate partner relationships, and alters } \\
\text { sexual attitudes and sexual behavior. }\end{array}$ \\
\hline Farré et al. [20] & 2019 & Spain & $\mathrm{E}$ & $1500(55.5)$ & 14-18 & $\begin{array}{l}\text { Direct association between pornography } \\
\text { use and risky sexual behaviors } \\
\text { (unprotected sex, contraception, sex after } \\
\text { alcohol and substances) in an adolescent } \\
\text { sample. Exposure to pornography may } \\
\text { affect psychosexual development in } \\
\text { adolescents. Pornography could lead to } \\
\text { more permissive sexual values. }\end{array}$ \\
\hline Garrido, M.F [21] & 2015 & Brazil & NE & - & - & $\begin{array}{l}\text { Internet access and globalization have } \\
\text { triggered a massive consumption of } \\
\text { pornography, which, in turn, can result in } \\
\text { addiction problems. }\end{array}$ \\
\hline Judge, A. M. [22] & 2012 & USA & NE & - & $12-19$ & $\begin{array}{l}\text { Relationship between sexting and the } \\
\text { creation and distribution of online child } \\
\text { pornography. }\end{array}$ \\
\hline $\begin{array}{l}\text { Karila, L., Wéry, A., } \\
\text { Weinstein, A., } \\
\text { Cottencin, O., Petit, } \\
\text { A., Reynaud, M., } \\
\text { and Billieux, J. [23] }\end{array}$ & 2014 & USA & NE & - & - & $\begin{array}{l}\text { Pornography consumption is a frequent } \\
\text { and idiosyncratic behavior of sexual } \\
\text { addiction or of hypersexual disorder. }\end{array}$ \\
\hline
\end{tabular}


Table 1. Cont.

\begin{tabular}{|c|c|c|c|c|c|c|}
\hline Citation & Year & Country & $\begin{array}{l}\text { Type of } \\
\text { Article }\end{array}$ & $\begin{array}{l}\text { N (\% of } \\
\text { Women) }\end{array}$ & $\begin{array}{l}\text { Age } \\
\text { Range }\end{array}$ & Results \\
\hline Ledesma, D. F. [24] & 2017 & Mexico & NE & - & - & $\begin{array}{l}\text { Addiction to online pornography shares } \\
\text { similar mechanisms with other traditional } \\
\text { addictions (such as drug abuse). Abuse of } \\
\text { pornography results in negative } \\
\text { brain effects. }\end{array}$ \\
\hline $\begin{array}{l}\text { Owens, E; Behun, } \\
\text { R; Manning, J and } \\
\text { Reid, R [25] }\end{array}$ & 2012 & EEUU & NE & - & $10-22$ & $\begin{array}{l}\text { Young people who consume more } \\
\text { pornography have more permissive sexual } \\
\text { attitudes, unrealistic sexual beliefs and } \\
\text { values, and even increased degrees of } \\
\text { sexually aggressive behavior. }\end{array}$ \\
\hline $\begin{array}{l}\text { Peter J. and } \\
\text { Valkenburg P. } \\
\text { M. [26] }\end{array}$ & 2008 & Netherlands & E & $2343(-)$ & $13-20$ & $\begin{array}{l}\text { Exposure to sexually explicit material is } \\
\text { associated with greater sexual uncertainty } \\
\text { in teens. }\end{array}$ \\
\hline $\begin{array}{l}\text { Peter, J., and } \\
\text { Valkenburg, P. } \\
\text { M. [3] }\end{array}$ & 2016 & Netherlands & NE & - & 10-17 & $\begin{array}{l}\text { Use of pornography was associated with } \\
\text { more permissive sexual attitudes and } \\
\text { stereotyped gender inequality thoughts. It } \\
\text { was also associated with an increase in } \\
\text { sexual aggression and high-risk } \\
\text { sexual practices. }\end{array}$ \\
\hline $\begin{array}{l}\text { Peter, J., and } \\
\text { Valkenburg, P. } \\
\text { M. [27] }\end{array}$ & 2009 & Netherlands & E & 962 & $13-20$ & $\begin{array}{l}\text { Exposure to sexually explicit material is } \\
\text { associated with the perception of women as } \\
\text { sexual objects. }\end{array}$ \\
\hline $\begin{array}{l}\text { Prause, N., Steele, } \\
\text { V. R., Staley, C., } \\
\text { Sabatinelli, D., and } \\
\text { Hajcak, G. [28] }\end{array}$ & 2015 & USA & $\mathrm{E}$ & $122(29.5)$ & $\begin{array}{l}(\mathrm{M}=24.4 \\
\mathrm{SD}=4.9)\end{array}$ & $\begin{array}{l}\text { Consumption of pornography is the most } \\
\text { frequently reported hypersexual behavior. }\end{array}$ \\
\hline $\begin{array}{l}\text { Rothman EF, } \\
\text { Kaczmarsky C, } \\
\text { Burke N, Jansen E, } \\
\text { Baughman A. [29] }\end{array}$ & 2015 & USA & $\mathrm{E}$ & $23(40)$ & $16-18$ & $\begin{array}{l}\text { Adolescents reported copying sexual } \\
\text { practices that they see in pornography } \\
\text { during their own sexual encounters. } \\
\text { Furthermore, they reported pressure to } \\
\text { imitate pornography as an element of } \\
\text { unhealthy intimate partner relationships. }\end{array}$ \\
\hline $\begin{array}{l}\text { Sánchez Zaldívar, } \\
\text { S., and Iruarrizaga } \\
\text { Díez, I. [9] }\end{array}$ & 2009 & Spain & NE & - & - & $\begin{array}{l}\text { The two most frequent types of internet } \\
\text { addiction are cybersex and porn. } \\
\text { Pornography consumption facilitates and } \\
\text { can trigger the appearance of voyeurism. }\end{array}$ \\
\hline $\begin{array}{l}\text { Stanley N, Barter C, } \\
\text { Wood M, Aghtaie } \\
\text { N, Larkins C, } \\
\text { Lanau A, } \\
\text { Överlien C. [30] }\end{array}$ & 2018 & $\begin{array}{l}\text { United } \\
\text { Kingdom }\end{array}$ & $\mathrm{E}$ & $4564(-)$ & 14-17 & $\begin{array}{l}\text { Pornography consumption was associated } \\
\text { with a higher likelihood of engaging in } \\
\text { sexting. Furthermore, youth with a regular } \\
\text { consumption of porn showed greater } \\
\text { negative attitudes towards gender. Finally, } \\
\text { sexual coercion and abuse carried out by } \\
\text { minors was significantly associated with a } \\
\text { regular consumption of online porn. }\end{array}$ \\
\hline $\begin{array}{l}\text { Svedin, C. G., } \\
\text { Akerman, I., and } \\
\text { Priebe, G. [31] }\end{array}$ & 2011 & Sweden & $\mathrm{E}$ & $4026(52.8)$ & 18 & $\begin{array}{l}\text { Frequent consumption of pornography has } \\
\text { been associated with many behavioral } \\
\text { problems, and adolescent males who } \\
\text { consumed pornography with greater } \\
\text { frequency showed having greater } \\
\text { sexual desire. }\end{array}$ \\
\hline $\begin{array}{l}\text { Vandenbosch, L., } \\
\text { and Eggermont, S. } \\
(2013)\end{array}$ & 2013 & Belgium & E & $911(89)$ & 15 & $\begin{array}{l}\text { Sexually explicit content or online } \\
\text { pornography contributes to the } \\
\text { internalization of body image ideals } \\
\text { amongst male teenagers. }\end{array}$ \\
\hline
\end{tabular}


Table 1. Cont.

\begin{tabular}{|c|c|c|c|c|c|c|}
\hline Citation & Year & Country & $\begin{array}{l}\text { Type of } \\
\text { Article }\end{array}$ & $\begin{array}{l}\mathbf{N}(\% \text { of } \\
\text { Women) }\end{array}$ & $\begin{array}{l}\text { Age } \\
\text { Range }\end{array}$ & Results \\
\hline $\begin{array}{l}\text { Villalobos, O. S., } \\
\text { and Díaz, V. C. [32] }\end{array}$ & 2017 & Spain & $\mathrm{NE}$ & - & - & $\begin{array}{l}\text { Problematic use of online pornography and } \\
\text { online sexual activity is associated with } \\
\text { sexual problems. }\end{array}$ \\
\hline $\begin{array}{l}\text { Voon, V., Mole, T. } \\
\text { B., Banca, P., Porter, } \\
\text { L., Morris, L., } \\
\text { Mitchell, S., Lapa, T. } \\
\text { R., Karr, J., } \\
\text { Harrison, N. A., } \\
\text { Potenza, M. N., and } \\
\text { Irvine, M. [33] }\end{array}$ & 2014 & $\begin{array}{l}\text { United } \\
\text { Kingdom }\end{array}$ & $\mathrm{E}$ & $38(0)$ & 19-25 & $\begin{array}{l}\text { Significant findings of brain activity } \\
\text { correlations when examining the } \\
\text { relationship between pornography } \\
\text { consumption and compulsive } \\
\text { sexual behavior. }\end{array}$ \\
\hline $\begin{array}{l}\text { Weber, M., Quiring, } \\
\text { O., and } \\
\text { Daschmann, G. [4] }\end{array}$ & 2012 & Germany & $\mathrm{E}$ & $352(41)$ & $16-19$ & $\begin{array}{l}\text { Consumption of pornography associated } \\
\text { with earlier sexual intercourse and more } \\
\text { varied sexual practices. }\end{array}$ \\
\hline $\begin{array}{l}\text { Wood, M., Barter, } \\
\text { C., Stanley, N., } \\
\text { Aghtaie, N., and } \\
\text { Larkins, C. [34] }\end{array}$ & 2015 & $\begin{array}{l}\text { United } \\
\text { Kingdom }\end{array}$ & $\mathrm{E}$ & $4564(-)$ & $14-17$ & $\begin{array}{l}\text { Teens who reported victimization behaviors } \\
\text { in their relationships showed higher } \\
\text { probabilities of having sent a sext. }\end{array}$ \\
\hline $\begin{array}{l}\text { Ybarra, M. L., and } \\
\text { Mitchell, K. J. [35] }\end{array}$ & 2005 & USA & $\mathrm{E}$ & $1501(-)$ & $10-17$ & $\begin{array}{l}\text { Minors who reported intentional exposure } \\
\text { to pornography were significantly more } \\
\text { likely to report criminal behaviors, drug } \\
\text { use, and depression. Pornography } \\
\text { consumption was associated with a higher } \\
\text { likelihood of perpetrating sexual } \\
\text { aggressions in males, and of being sexually } \\
\text { victimized in females. }\end{array}$ \\
\hline
\end{tabular}

Note: E = Empirical study, NE = Non-Empirical study, - = No data found. ${ }^{* *}$ Note: Ballester et al.'s studies used participants aged 16-29, although the results reported in this review are the ones regarding disaggregated data from the 16-22 age group.

\subsection{Social and Psychological Problems Associated with Pornography Consumption in Adolescents 3.1.1. Pornography Addiction}

As mentioned above, watching and consuming pornography is a well-extended practice among youth nowadays. Considering that statement, it becomes relevant to highlight that, although the consumption of pornography can begin at early ages (typically during adolescence), it is usually not until adulthood when difficulties or alterations associated with its consumption manifest. One of the main issues regarding the consumption of pornography is that immediate, easily accessible, and unrealistic visual stimuli reinforce and facilitate addiction (Ledesma 2017).

Laier, Pawlikowski, Pekal, and Paul [36] concluded in their research that online pornography addiction and substance addictions share basic underlying neurobiological mechanisms and that they are analogous processes that produce in the addict a need for a higher and more frequent dose, with the particularity that in pornography consumption, stimuli are more immediate and more easily accessed (through a click) than drugs.

Further research has also established a clear association between substance abuse and behavioral addictions. Both categories share common characteristics, such as tolerance to the addictive stimulus and shared neurobiological routes. Grant, Brewer, and Potenza [37] have highlighted three common symptoms of both substance abuse and behavioral addictions: hyperreactivity to the addictive stimulus, an anesthetic effect of pleasure, and gradual impairment of will. Dodge (2008) analyzed neuroplastic changes in those who compulsively and chronically consumed pornography, finding that the individuals who were addicted needed more pornographic material, new stimuli, and harder content to maintain the same excitement levels. A recent literature review concluded that online pornography use is on the rise, with a potential for addiction considering the "triple A" influence: accessibility, affordability, and anonymity [15]. According to the authors, this problematic use 
and abuse of pornography might have adverse effects on sexual development and sexual functioning, especially among the young population [15].

Finally, repeated and compulsive consumption of pornography can also have important implications and alterations in youth. A recent study showed that $60 \%$ of the analyzed sample showed serious difficulties to have erections or get excited with their real partners but could do so when watching pornographic content online [33]. Further research using 3T magnetic resonance imaging scans also found an association between the number of hours a week spent watching pornographic content and structural and functional brain alterations, with specific findings showing a negative association between reported pornography hours per week and functional activity during a sexual cue-reactivity paradigm in the left putamen [38]. Kühn and Gallinat [38] reported that their findings evidenced that those who consumed pornography for a higher amount of time had developed tolerance to such content, confirming the hypothesis that high exposure to pornographic stimuli can result in a decrease in the neurological response to natural sexual stimuli. Despite the fact that Kühn and Gallinat's results were obtained using an adult sample of ages 21-45 years old, it could be expected that long-term consumption of pornography might start having an effect on the brain at an earlier life stage, such as youth [38].

\subsubsection{Hypersexualization and Hypersexuality}

It has been seen that some consequences of consuming and being addicted to pornography are experiencing an increase in sexuality (hypersexuality), hypersexualization of the environment and intimate relationships, and developing a sex addiction (autoeroticism or with sexual partners). In this sense, Fagan [19] stated in his review that the consumption of pornography significantly distorts attitudes and ideas about the nature of sexual relationships. Regarding compulsive behaviors or sexual addiction, Cooper, Galdbreath, and Becker [39] reported that online sexual activity was carried out by participants in order to face daily problems, and other research has linked pornography consumption with compulsive and impulsive behaviors [23]. Even though both authors' results are obtained using an adult sample $(+18)$, it is important to point out that youth is an especially impulsive life period, which could be intimately related to their findings. In this regard, Efrati and Gola [17] confirmed that youth who present compulsive sexual behavior (CSB) have a higher frequency of pornography use [17].

Several studies have established the effect of pornography consumption and its influence on the sexual attitudes, moral values, and sexual activity of young people $[5,8,20]$. Given that young people often claim that they use pornography as a way to obtain sexual knowledge and information, it might be plausible to consider that such consumption can have an effect and impact on their knowledge about sexuality and their subsequent sexual practices $[3,20,25,27]$. Up to date, the literature has shown that porn consumption can impact youths' knowledge about sexuality in practices such as compulsive sexual behavior, precocious sexual activity, and more variety of sexual practices [4]. Furthermore, porn consumption has a learning effect on youth who might end up emulating pornographic videos in real life, as well as engaging in high-risk sexual practices they have watched online $[3,13,29]$. Other studies have shown the relationship between the consumption of pornography in young people with a significant increase in the uncertainty about their own sexuality and more positive attitudes towards uncommitted sexual exploration [26].

The laxity and permissiveness that pornography can promote with regard to the experience of sexuality have a direct impact on the way it is conceived and practiced, which is why some data highlights that the consumption of pornography can lead to an increase in sexuality (hypersexuality), understood as an impulsive, compulsive sexual behavior $[17,33]$. Taking into account that the consumption of pornography usually begins at an early age, it can be deduced that when faced with this consumption, young people might be exposing themselves to risk factors for developing non-adaptive sexuality. In this sense, it has been found that young people who consume more pornography have more permissive sexual attitudes, unrealistic sexual beliefs and values, and consistent findings 
have emerged linking adolescents' use of pornography that depicts violence with increased degrees of sexually aggressive behavior $[20,25]$.

Research has shown that consuming pornography can be related to developing hypersexualized behaviors and that hypersexuality can lead to risky experiences, which increases the probability of developing physical and mental health problems [19]. Regarding hypersexuality in adolescents and youth, it has been found that those who present compulsive sexual behavior (CSB) reported a higher frequency of pornography use and more sexrelated online activities than adolescents with a lower frequency of porn consumption, which highlights the role of pornography consumption in altered sexual behaviors in youth [17]. Likewise, a Swedish study carried out with 4026 adolescents (18 years old) showed that the frequent consumption of pornography was associated with many behavioral problems, and reported that frequent pornography users had a greater sexual desire and had sold sex more often than other boys the same age [31].

\subsubsection{Ritualization or Distortion of Interpersonal and Sexual Relationships}

Furthermore, recent literature has highlighted the impact of consuming pornography on sexual behaviors and gender equality. The fact that young people consume pornography for educational purposes, due to a lack of references in sexual education, is particularly relevant. This habit might contribute to the appearance of imitational patterns, by trying to copy and reproduce in their own sexual encounters the sexual practices learned from pornography, and some young people might feel pressured to do or imitate such pornographic content in real life, with the risk of presenting dysfunctional consequences for themselves or others [29].

The rapid development of the Internet has been a conditioning factor regarding pornography consumption. The online world enables and facilitates the creation of new forms of social interaction, with the possibility of performing uninhibited sex practices. In many cases, these online sex practices are indiscriminate, anonymous, uncommitted, easy, and exempt from responsibilities, which can significantly condition and distort the understanding of sexuality and affection, especially in youth. A recent report developed by Save the Children established that almost $15 \%$ of their teenage sample (14-17 years old) reported that frequently consuming pornography had seriously affected their personal relationships, and $37.4 \%$ reported that it had affected their personal relationships "a lot" [13].

Ballester et al. (2014) indicated that one of the most relevant effects of consuming new pornography in young people is the increasing ritualization of relationships, modifying the understanding of social relationships, expectations, the criteria to evaluate them, the modalities of desired sexual practices, and other aspects of interpersonal relationships. In their research, carried out using a sample of 37 participants aged 16-29 years old, and a subsample of 19 participants aged 16-22 years old, Ballester et al. [5] found that one attitude that is clearly modified due to pornography consumption in young people is the acceptance of high-risk sexual practices, such as vaginal sex without a condom, frequently changing partners, group sex, anal sex without a condom with different partners, and so forth.

Furthermore, a recent study highlighted that ritualizing intimate relationships can have diverse consequences, among which they point out increasing difficulties to establish and maintain effective and sexual interpersonal relations, distorted expectations, which can result in greater failure when socially interacting, and poor levels of global functionality [1]. In particular, in their review, they pointed out that one of the possible negative consequences of exposure to new pornography is that it can lead young people to believe that they should emulate the practices they have observed (for example, non-consensual sex, violent sexual practices, copying illegal activities observed in extreme pornography, or engaging in risky sexual practices seen on the Internet), without a clear conviction or education about healthy and safe sexuality. Finally, it is suggested that as a result of the consumption of pornography, there may be an escalation of "hardcore" practices, as con- 
sumers need bigger and more violent stimuli to reach satisfaction after frequent exposure to sexual content [1].

It should be noted that young people's sexual identities are shaped by the education and information they receive and are modulated by the experiences they live. Considering this premise, one of the risks of youth consuming pornography is that the unrealistic vision of sex that is shown in pornography can act as a "sexual mentor", thus enhancing a distorted knowledge of what healthy sexual relationships ought to be [18].

In their research, Esquit and Alvarado [18] concluded that the consumption of pornography can negatively impact youths' psychosexual development, including consequences such as a predisposition to developing a dependence on or an addiction to pornography, abnormal sexual development and unrealistic expectations, predisposition to promiscuity, a lack of contraceptive methods, vulnerability to sexually transmitted diseases, and a distortion of the parameters of healthy sexual behavior and self-image.

Furthermore, consuming pornography at early stages of youth can facilitate the development of distorted ideas related to gender roles in sexual relationships (such as understanding men as the dominant gender and women as submissive or as a sexual object), which could favor the normalization of pathological sexual behaviors, distortions in sexual relationships, and the appearance of anti-normative, antisocial, or violent behaviors, as will be shown throughout the paper. In this regard, Stanley et al. [30] found in their research that the consumption of regular pornography was associated with a greater tendency to have negative gender attitudes, and with higher levels of perpetration of sexual coercion and abuse, highlighting a positive relationship between such consumption and coercion, sexual abuse, and behaviors such as "sexting".

\subsection{Forensic Implications and Challenges Associated with Pornography Consumption in Youth}

Besides the abovementioned association between consuming pornography and the social, psychological, and sexual consequences, the consumption of pornography has also been associated with legal and criminal behaviors that have a direct impact on forensic practice. Thus, the present study will analyze some of the forensic challenges and implications associated with the consumption of pornography in youth, such as the development of paraphilias associated with pornography consumption, the increase in sexual aggression perpetration and victimization in young people, and, finally, as causality and consequence, the development of new forms of online sexual victimization related to pornography, such as sexting and online grooming.

\subsubsection{Pornography Consumption and Paraphilias}

The relationship between pornography consumption and the development of maladjusted sexual tendencies is heterogenous and inconclusive. In this regard, Ybarra and Mitchell (2005) found an association between pornography consumption in youth and engagement in criminal behaviors, substance abuse, depression, and an insecure attachment, suggesting that pornography consumption in youth could be contributing to the development of paraphilias.

The majority of authors point out that the association between pornography consumption and paraphilias is not direct, and they highlight that consuming pornography could be a way to discover, trigger, and/or exacerbate an underlying and undeveloped paraphilia [9]. In this sense, research has found that the higher and earlier exposure to sexual content, the greater the risk of developing paraphilias [10]. Thus, paraphilias most frequently associated with pornography consumption are voyeurism and exhibitionism $[9,10]$. Voyeurism, as a paraphilia, is associated with pornography consumption by which the person watches erotic sexual content, but also pornography consumption gives the voyeur the opportunity to watch content that has not been filmed with the intention of creating pornography and feed their voyeuristic fantasies [9]. Moreover, the association between exhibitionism and pornography consumption becomes clear when seeing that the accessibility exhibitionists 
have to show their sexual organs online through webcams or record self-produced sexual content and upload it online [9].

Finally, despite the fact that it has not been possible to establish a direct relationship between pornography consumption and the development of other paraphilias, it has become clear that consuming "hardcore" pornography or violent content can facilitate the development of paraphilias, such as sexual sadism or pedophilia, and moreover, encourage and exacerbate the desire to carry out criminal behaviors either in the physical space (such as sexual assaults or pederasty) or in the virtual space (such as sexting or online grooming) [9]. Furthermore, some literature has shown that pornography consumption follows a gradual progression depending on the first age of consumption. These findings were extracted from an adult sample study, but it highlighted that the individuals who started intentional pornography exposure at earlier stages showed a higher probability of consuming non-conventional and paraphilic pornography later on, as opposed to those who were intentionally exposed to pornography at an older age [40]. From these results, it could be inferred that if early intentional exposure to porn is linked to the consumption of paraphilic pornography at later stages in adults, the earlier the exposure starts the bigger effect it might have on the consumer, meaning that if intentional exposure starts at youth, the effects of such early exposure might be even bigger than the ones found in adults.

\subsubsection{Sexual Aggression Perpetration and Victimization}

As previously mentioned, Sánchez and Iruarrizaga [9] suggest that consuming pornography can encourage and facilitate the commission of sexual crimes because it can contribute to the normalization of certain violent behaviors within sexual relationships. A recent study carried out with Spanish adolescents found that $72 \%$ of the sample considered that the pornography content they consumed was violent [13], and consistent findings have emerged linking the adolescent use of pornography that depicts violence with increased degrees of sexually aggressive behavior [25]. Additionally, various investigations have found a solid correlation between pornography consumption in minors and an increase in physical sexual assaults, especially in minors that consumed violent pornographic content [14,41]. In this sense, Ybarra et al. [41] conducted a longitudinal study with 1588 teenagers (between 14 and 19 years old) and observed that the minors who had consumed violent pornography were six times more likely to perpetrate sexually aggressive behaviors.

A study carried out by Ybarra and Mitchell [35] found that, of all the men that presented risks of showing violent behaviors, those that frequently consumed pornography were four times more likely to sexually assault someone than men who did not consume pornography frequently. Moreover, a recent literature review highlighted the relationship between pornography consumption and sexual aggressions in teenagers [3].

With regards to sexual assault perpetration triggered by pornography consumption, the investigation carried out by Bonino et al. [14] with a sample of Italian adolescents showed that consuming pornography was associated with sexually harassing a partner or forcing someone to maintain sexual relationships. Moreover, the study carried out by Ybarra et al., [41] found that the perpetration of sexual assault was associated with the consumption of violent pornographic material but not with the consumption of general non-violent pornography. Moreover, Stanley et al. [30] conducted a study with a sample comprising 4564 teenagers aged 14-17 years old and found that boys' perpetration of sexual coercion and abuse was significantly associated with regular viewing of online pornography.

Finally, regarding pornography consumption and sexual victimization, Bonino et al. [14] in their sample of Italian teenagers found out that girls that had consumed more pornographic content had more probabilities of being victims of sexual violence than girls who had not consumed as much pornography. 


\subsubsection{Sexting and Other Forms of Online Sexual Victimization}

The rapid development of new technologies and instant communication through the internet has brought the development of new ways of social interaction. Some of these forms of social interaction are not harmful nor have negative effects; however, the online environment can entail risks that can enable the development of new forms of online victimization, both non-sexual and sexual. As such, pornography consumption by young people has been associated with a new form of online sexual interaction known as sexting [8]. Sexting refers to sending, receiving, or forwarding sexually explicit text messages, images, or videos through electronic devices, especially mobile phones. The previous literature has found that the participants who engaged in sexting had more accepting attitudes towards pornography consumption and consumed more pornography themselves than those who did not engage in sexting behaviors. In this regard, research conducted with a sample of 4564 European adolescents found that viewing online pornography was associated with a significantly increased probability for boys of having sent sexual images/messages in nearly all of the studied countries [30], in line with a recently published report on the consumption of pornography amongst Spanish adolescents [13]. The study carried out by Save the Children surveyed 1680 teens aged $14-17$ and found that $20.2 \%$ of teenagers who consume pornography have shared autoproduced sexual content at least once, and they reported significant differences in sexting engagement between porn consumers and non-consumers, with consumers engaging more frequently in sexting practices than nonconsumers [13]. Furthermore, the consumption of pornography has been significantly associated with contacting unknown people online for sexual purposes, which is risky behavior that can lead to other forms of victimization, such as online grooming, sexting coercion, or image-based sexual abuse [42]. The recent investigation presented by Save the Children reports that $17 \%$ of teenagers who consume pornography have contacted an unknown person online for sexual purposes, and that $1.6 \%$ of the participants who consume pornography reported frequently contacting an unknown person online for sexual purposes [13].

Sexting itself poses many risks for teenagers, such as being a victim of non-consensual dissemination of the sexual content or being pressured or coerced into sending sexual content [43]. Furthermore, derived from the engagement in sexting and the non-consensual dissemination of sexual content, people involved in these behaviors can become victims of cyberbullying, sexual cyberharassment, sextortion, and, in the case of minors, they can also become victims of online grooming [43]. Engaging in sexting behaviors has an additional risk for minors, since the autogenerated sexual content can be considered to be child pornography, and teenagers are starting to create and distribute their own pornography [44]. Additionally, research has found an association between sexting and sexual partner violence amongst young people, with results indicating that girls who had been a victim of sexual violence (forced or pressured) were significantly more likely to have sent a sexual image than those who had not been victims of sexual violence [34].

These behaviors and forms of online sexual victimization have been linked by many authors to psychopathological consequences [43]. Van Ouytsel, Van Gool, Ponnet, and Walrave [45] associated engaging in sexting behaviors with higher levels of depression, anxiety, and substance abuse, whilst Dake, Price, Maziarz, and Ward [46] found a significant association between engaging in sexting and higher levels of depression and suicidal thoughts. Furthermore, the consumption of pornography and engaging in sexting behaviors are both risky behaviors, associated with online grooming victimization, as higher consumption of pornography and a higher engagement in sexting would raise the probabilities of being a victim of online grooming [47].

The abovementioned data shows and evidences the existing association between the consumption of pornography in minors and new forms of online sexual victimization, such as sexting, cyberbullying, sextortion, and online grooming. Moreover, it confirms the association between emotional alterations and psychopathological symptoms, highlighting the importance of an accurate evaluation of the different phenomena in forensic practice $[42,43]$. 


\section{Discussion and Conclusions}

Young people's psychological development and socialization are undergoing important changes due to the irruption of technology in daily life, and many of their interactions have moved to the online world. In this new virtual world known as cyberspace, youth have access to all kinds of content, including pornography, with research showing that the age of first exposure to online sexual content in Spain is around 8 years old, with generalized consumption beginning at 13-14 years old [1]. In this sense, unlimited access to electronic devices has enabled a new way of accessing and consuming pornography in youth that can have a great impact on their sexual development and gender equality in relationships, with the consequent appearance of sexual alterations and forensic implications.

Regarding the consequences derived from the consumption of pornography in youth, studies indicate that the inherent characteristics of new pornography (immediacy and accessibility) reinforce the paradigm of addiction, resulting in a process similar to that of drug addiction, with shared neurobiological pathways, leading to dysfunctional consequences, such as neuroplastic changes and sexual dysfunctions in individuals with addiction [33,38]. Moreover, consuming pornography at early stages can be a predisposing factor for developing hypersexualized behaviors; in fact, the consumption of pornography is the most frequently reported hypersexual behavior [28]. In this sense, research has found that higher pornography use and sex-related online activities are associated with compulsive sexual behavior in youth, and the frequent consumption of pornography is associated with many behavioral problems, highlighting the role of pornography consumption in altered sexual behaviors in young people $[17,31]$.

Several studies have established the effect of pornography consumption and its influence on sexual attitudes, moral values, and sexual activity in young people $[5,8,20]$. Given that young people often claim that they use pornography as a way to obtain sexual knowledge and information, it might be plausible to consider that such consumption can have an effect and impact on their knowledge about sexuality and their subsequent sexual practices, such as compulsive sexual behavior, precocious sexual activity, and more variety of sexual practices $[3,4,20,25,27]$. Furthermore, porn consumption can have a learning effect on youth who end up emulating pornographic videos in real life, as well as engaging in high-risk sexual practices they have watched online $[3,13,29]$.

Additionally, pornography consumption has been especially associated with a greater tendency to have negative gender attitudes $[1,30]$. Likewise, hypersexuality and the consumption of pornography can lead to unsafe and risky sexual practices and are associated with the increased comorbidity of mood disorders and substance use. Overall, research has found that the consumption of pornography can contribute to the ritualization or distortion of interpersonal and sexual relationships and the decontextualization of sexuality, which is a risk factor for the unhealthy development of an individual. It is suggested that as a result of the consumption of pornography, there may be an escalation of "hardcore" practices, as consumers need bigger and more violent stimuli to reach satisfaction after frequent exposure to sexual content [1]. In this sense, it should be noted that young people consume pornography, among others, for educational purposes, due to a lack of references in sexual education, and this may contribute to the appearance of imitational patterns. Young people might feel pressured to do or imitate pornography in real life, with the risk of presenting dysfunctional consequences for themselves or others [29].

Considering the forensic implications associated with the consumption of pornography in youth, studies have shown an association with the development of paraphilias, such as voyeurism and exhibitionism, and in this sense, it has been observed that the greater and earlier the exposure to sexual content, the more likely it is that young people might end up manifesting a paraphilia. Additionally, consuming "hardcore" pornography or sexually violent content could fuel the development of sexual sadism and pedophilia, as well as exacerbate the desire to carry out certain criminal behaviors, both in the physical and in the virtual [25]. Along the same lines, research has shown a link between pornography consumption and an increased risk of victimization and perpetration of sexual aggression; 
the results indicate that greater consumption of pornography increases the likelihood of perpetrating sexual violence in men and increases the likelihood of being a victim of sexual violence in women [14,35]. Regarding the forms of online sexual victimization, the consumption of pornography in youth has been related to sexting, and this victimization may be extended to other new behaviors, such as the non-consensual dissemination of sexual content, cyberbullying, sextortion, and online grooming. Recent research has highlighted that one out of five teenagers who consume pornography have shared autoproduced sexual content, and significant differences have been found in sexting behaviors between those who watch porn and those who do not [30]. Furthermore, pornography consumption has been significantly associated with contacting unknown people online for sexual purposes, which is risky behavior that can lead to other forms of victimization, such as online grooming, sexting coercion, or image-based sexual abuse [42].

Conclusively, the growing consumption of pornography in youth entails notable risks and implications in the emotional and sexual development of youth, contributing to the appearance of new criminal typologies and forms of online sexual victimization. In general, results from this narrative review highlight the impact that consuming pornography can have on healthy social and emotional development in young people, especially when the consumption of sexually explicit content takes place in the early stages of teen development. Our results indicate that early intentional exposure to pornographic content can negatively influence youths' behavior by facilitating hypersexualization and contributing to the perpetuation of gender inequality patterns in sexual and emotional relationships. Furthermore, early consumption of pornography has been linked to several forensic implications, such as the exacerbation of paraphilias and the increase in online and offline sexual aggression perpetration and victimization, which, in turn, can have a negative impact on youth development. Future lines of research should assess the real, immediate, and future impact of the presented issues and challenges, as well as establish specific prevention, detection, and intervention plans targeted at vulnerable groups.

\section{Limitations}

This study has been conducted as a narrative review to identify empirical and nonempirical research addressing the association between pornography consumption in young people and the social, sexual, and psychological consequences as well as further forensic implications, which enables a first approach and approximation to the state of the question and the psychological and forensic challenges regarding pornography consumption in youth. A further and deeper study of the presented topic should be carried out using systematic review methodology, and, thus, results presented in the study should be generalized with caution. It should be noted that technological advances mean that the literature in this field is very quickly dated and papers from 2012 and earlier may not completely reflect the current picture. Likewise, it should be noted that most of the reviewed studies did not specify the type of pornography used in their research (heterosexual, queer, feminist, etc.), and, the studies that did, analyzed exclusively heterosexual pornography. Further research should assess the impact of different types of pornography on the young population.

Author Contributions: Conceptualization, A.M.G. and A.B.-G.; methodology, A.M.G. and A.B.-G.; writing —original draft preparation, A.B.-G.; writing—review and editing, A.M.G. All authors have read and agreed to the published version of the manuscript.

Funding: This research received no external funding.

Institutional Review Board Statement: Not applicable.

Informed Consent Statement: Not applicable.

Conflicts of Interest: The authors declare no conflict of interest. 


\section{References}

1. Ballester, L.; Orte, C.; Pozo, R. Nueva pornografía y cambios en las relaciones interpersonales de adolescentes y jóvenes. Vulnerabil. Resist. Exp. Investig. 2019, 249-286. Available online: https://conversesacatalunya.cat/wp-content/uploads/2019/06/TF1 7PORNOGRAFIA.pdf (accessed on 8 March 2021).

2. Agustina, Sanllehi, J. La pornografía. Sus efectos sociales y criminógenos. Una aproximación multidisciplinar. Actual. Criminol. Penal. Madr. Edisofer 2011. Available online: https://www.researchgate.net/publication/329182643_La_pornografia_y_sus_ efectos_sociales_y_criminogenos_Una_aproximacion_multidisciplinar (accessed on 8 March 2021).

3. Peter, J.; Valkenburg, P.M. Adolescents and pornography: A review of 20 years of research. J. Sex Res. 2016, 53, 509-531. [CrossRef]

4. Weber, M.; Quiring, O.; Daschmann, G. Peers, parents, and pornography: Exploring adolescents' exposure to sexually explicit material and its developmental correlates. Sex. Cult. 2012, 16, 408-427. [CrossRef]

5. Ballester, L.; Orte, C.; Pozo, R. Estudio de la nueva pornografía y relación sexual en jóvenes. Rev. Andal. Cienc. Soc. 2014, 165-178. [CrossRef]

6. Jiménez, A.G.; De-Ayala-López, M.C.; García, B.C. Hábitos de uso en Internet y en las redes sociales de los adolescentes españoles. Comunicar 2013, 41, 195-204.

7. Villena, A.; Chiclana, C. Consequence of pornography use: Brief report. Psicosom. Psiquiatr. 2019, 9, 18-25.

8. Burbano, M.V.T.; Brito, J.P.S. La pornografía y su incidencia en el desarrollo psicosexual de adolescentes. Uniandes Epistem. 2019, 6, 246-260.

9. Sánchez Zaldívar, S.; Iruarrizaga Díez, I. Nuevas dimensiones, nuevas adicciones: La adicción al sexo en internet. Psychosoc. Interv. 2009, 18, 255-268. [CrossRef]

10. Villalobos, O.S.; Díaz, V.C. Tecno-adicción al sexo en la población juvenil: Propuesta del diseño de una escala de detección temprana. Rev. Comun. Salud 2017, 7, 119-149. [CrossRef]

11. Agustina, J.R.; Gómez-Durán, E.L. Factores de riesgo asociados al sexting como umbral de diversas formas de victimización. Estudio de factores correlacionados con el sexting en una muestra universitaria. Rev. Internet Derecho Politica 2016, $22,21-47$. [CrossRef]

12. Rother, E. Systematic literature review X narrative review. Acta Paul Enferm 2007, 20, 1-2. [CrossRef]

13. Barroso, L.; Sanjuán, C. (Des) Información sexual: Pornografía y Adolescencia. Un Análisis Sobre el Consumo de Pornografía en Adolescentes y su Impacto en el Desarrollo y las Relaciones con Iguales; Save the Children: Fairfield, CT, USA, 2020.

14. Bonino, S.; Ciairano, S.; Rabaglietti, E.; Cattelino, E. Use of pornography and self-reported engagement in sexual violence among adolescents. Eur. J. Dev. Psychol. 2006, 3, 265-288. [CrossRef]

15. de Alarcón, R.; de la Iglesia, J.I.; Casado, N.M.; Montejo, A.L. Online Porn Addiction: What We Know and What We Don't-A Systematic Review. J. Clin. Med. 2019, 8, 91. [CrossRef] [PubMed]

16. Echeburúa, E. ¿Existe realmente la adicción al sexo? Adicciones 2012, 24, 281-286. [CrossRef]

17. Efrati, Y.; Gola, M. Understanding and predicting profiles of compulsive sexual behavior among adolescents. J. Behav. Addict. 2018, 7, 1004-1014. [CrossRef]

18. Esquit, L.; Alvarado, Y. Pornografía y su Impacto en el Desarrollo Psicosexual del Adolescente; Universidad de San Carlos de Guatemala: Antigua Guatemala, Guatemala, 2016.

19. Fagan, P.F. The effects of pornography on individuals, marriage, family and community. Marriage Relig Res. Inst. 2009, 1-26. Available online: https:/ / marri.us/wp-content/uploads/The-Effects-of-Pornography-on-Individuals-Marriage-Family-andCommunity.pdf (accessed on 8 March 2021).

20. Farré, J.M.; Montejo, A.L.; Agulló, M.; Granero, R.; Chiclana Actis, C.; Villena, A.; Maideu, E.; Sánchez, M.; Fernández-Aranda, F.; Jiménez-Murcia, S.; et al. Pornography Use in Adolescents and Its Clinical Implications. J. Clin. Med. 2020, 9, 3625.

21. Garrido, M.F. La globalización. Las redes sociales y la adicción sexual. Dianova Esp. Infonova 2015, 28, 47-54.

22. Judge, A.M. "Sexting" among US adolescents: Psychological and legal perspectives. Harv. Rev. Psychiatry 2012, $20,86-96$. [CrossRef]

23. Karila, L.; Wéry, A.; Weinstein, A.; Cottencin, O.; Petit, A.; Reynaud, M.; Billieux, J. Sexual addiction or hypersexual disorder: Different terms for the same problem? A review of the literature. Curr. Pharm. Des. 2014, 20, 4012-4020. [CrossRef]

24. Ledesma, D.F. Así en el porno como en las drogas Sobre la neurobiología de la adicción al porno. DL Feregrino-2017-Cienc. 2017, 9, $1-10$.

25. Owens, E.; Behun, R.; Manning, J.; Reid, R. The Impact of Internet Pornography on Adolescents: A Review of the Research. Sex. Addict. Compulsivity 2012, 19, 99-122. [CrossRef]

26. Peter, J.; Valkenburg, P.M. Adolescents' Exposure to Sexually Explicit Internet Material, Sexual Uncertainty, and Attitudes Toward Uncommitted Sexual Exploration: Is There a Link? Commun. Res. 2008, 35, 579-601. [CrossRef]

27. Peter, J.; Valkenburg, P.M. Adolescents' exposure to sexually explicit internet material and notions of women as sex objects: Assessing causality and underlying processes. J. Commun. 2009, 59, 407-433. [CrossRef]

28. Prause, N.; Steele, V.R.; Staley, C.; Sabatinelli, D.; Hajcak, G. Modulation of late positive potentials by sexual images in problem users and controls inconsistent with "porn addiction". Biol. Psychol. 2015, 109, 192-199. [CrossRef]

29. Rothman, E.F.; Kaczmarsky, C.; Burke, N.; Jansen, E.; Baughman, A. “Without porn ... i wouldn't know half the things i know now": A qualitative study of pornography use among a sample of urban, low-income, black and Hispanic youth. J. Sex Res. 2015, 52, 736-746. [CrossRef] [PubMed] 
30. Stanley, N.; Barter, C.; Wood, M.; Aghtaie, N.; Larkins, C.; Lanau, A.; Överlien, C. Pornography, sexual coercion and abuse and sexting in young people's intimate relationships: A European study. J. Interpers. Violence 2018, 33, 2919-2944. [CrossRef] [PubMed]

31. Svedin, C.G.; Akerman, I.; Priebe, G. Frequent users of pornography. A population based epidemiological study of Swedish male adolescents. J. Adolesc. 2011, 34, 779-788. [CrossRef]

32. Vandenbosch, L.; Eggermont, S. Sexualization of adolescent boys: Media exposure and boys' internalization of appearance ideals, self-objectification, and body surveillance. Men Masc. 2013, 16, 283-306. [CrossRef]

33. Voon, V.; Mole, T.B.; Banca, P.; Porter, L.; Morris, L.; Mitchell, S.; Lapa, T.R.; Karr, J.; Harrison, N.A.; Potenza, M.N.; et al. Neural correlates of sexual cue reactivity in individuals with and without compulsive sexual behaviours. PLoS ONE 2014, 9, e102419. [CrossRef]

34. Wood, M.; Barter, C.; Stanley, N.; Aghtaie, N.; Larkins, C. Images across Europe: The sending and receiving of sexual images and associations with interpersonal violence in young people's relationships. Child. Youth Serv. Rev. 2015, 59, 149-160. [CrossRef]

35. Ybarra, M.L.; Mitchell, K.J. Exposure to Internet pornography among children and adolescents: A national survey. Cyberpsychol. Behav. 2005, 8, 473-486. [CrossRef]

36. Laier, C.; Pawlikowski, M.; Pekal, J.; Schulte, F.P.; Brand, M. Cybersex addiction: Experienced sexual arousal when watching pornography and not real-life sexual contacts makes the difference. J. Behav. Addict. 2013, 2, 100-107. [CrossRef]

37. Grant, J.E.; Brewer, J.; Potenza, M. The neurobiology of substance and behavioral addictions. CNS Spectr. 2006, 11, 924-930. [CrossRef] [PubMed]

38. Kühn, S.; Gallinat, J. Brain structure and functional connectivity associated with pornography consumption: The brain on porn. JAMA Psychiatry 2014, 71, 827-834. [CrossRef]

39. Cooper, A.; Galbreath, N.; Becker, M.A. Sex on the Internet: Furthering Our Understanding of Men With Online Sexual Problems. Psychol. Addict. Behav. 2004, 18, 223-230. [CrossRef]

40. Seigfried-Spellar, K.; Marcus, K.R. Does deviant pornography use follow a Guttman-like progression? Comput. Hum. Behav. 2013, 29, 1997-2003. [CrossRef]

41. Ybarra, M.L.; Mitchell, K.J.; Hamburger, M.; Diener-West, M.; Leaf, P.J. X-rated material and perpetration of sexually aggressive behavior among children and adolescents: Is there a link? Aggress. Behav. 2011, 37, 1-18. [CrossRef]

42. Gassó, A.M.; Fernández-Cruz, V.; Montiel, I.; Martin-Fumadó, C.; Agustina, J.R. Retos forenses ante la cibercriminalidad social en menores. Rev. Esp. Med. Leg. 2019, 45, 73-76. [CrossRef]

43. Gassó, A.M.; Klettke, B.; Agustina, J.R.; Montiel, I. Sexting, mental health, and victimization among adolescents: A literature review. Int. J. Environ. Res. Public Health 2019, 16, 2364. [CrossRef]

44. Agustina, J.R. ¿Menores infractores o víctimas de pornografía infantil? Respuestas legales e hipótesis criminológicas ante el Sexting. Rev. Electrón. Cienc. Penal Criminol. 2010, 12, 1-44.

45. Van Ouytsel, J.; Van Gool, E.; Ponnet, K.; Walrave, M. Brief report: The association between adolescents' characteristics and engagement in sexting. J. Adolesc. 2014, 37, 1387-1391. [CrossRef]

46. Dake, J.A.; Price, J.H.; Maziarz, L.; Ward, B. Prevalence and correlates of sexting behavior in adolescents. Am. J. Sex. Educ. 2012, 7, 1-15. [CrossRef]

47. Villacampa, C. Teen sexting: Prevalence, characteristics and legal treatment. Int. J. Law Crime Justice 2017, 49, 10-21. [CrossRef] 